University of South Carolina

Scholar Commons

8-1978

\title{
Reaching the Peasant Farmer: Organization Theory and Practice in Kenya by David K. Leonard
}

Mark W. DeLancey

University of South Carolina - Columbia, mwdelancey@yahoo.com

Follow this and additional works at: https://scholarcommons.sc.edu/poli_facpub

Part of the Political Science Commons

\section{Publication Info}

Published in Journal of Politics, Volume 40, Issue 3, 1978, pages 809-811.

http://journals.cambridge.org/action/displayJournal?jid=JOP

(C) 1978 by Cambridge University Press

This Book Review is brought to you by the Political Science, Department of at Scholar Commons. It has been accepted for inclusion in Faculty Publications by an authorized administrator of Scholar Commons. For more information, please contact digres@mailbox.sc.edu. 
compelled to grant that Rousseau is if anything more hostile to the moral content of Chrisianity than was Machiavelli (pp. 199-201). Lemos's defense of Christianity against Rousseau's attack manages not to mention the post-Reformation wars of religion that crucially affected three centuries of European political thought.

Space will not permit a detailed examination of all the problems of interpretation raised by this book. One more example must suffice. Lemos grasps the central importance of Rousseau's distinction between amour de soi and amour-propre. But his analysis of amour-propre transforms it into a variant of Aristotle's pleonexia: the desire to have more than others or more than one's fair share, even at the expense of others. There is some truth to this, but it omits the crucial point. The core of amour-propre is the desire to be recognized as superior by others. There is thus an unbroken line from Hobbes's discussion of pride, through Rousseau, to Hegel's famous discussion of the life-and-death struggle for recognition.

This book is not wholly without merit. It contains a clear (if unoriginal) account of the different senses of "freedom" in Rousseau, and its discussion of the relation between Rousseau and Marx, though inadequate, reminds us that a satisfactory full-length treatment of this important problem has yet to be written. But, considering everything, this book is too idiosyncratic to serve as an introduction to Rousseau's political philosophy and too general to be a significant scholarly contribution.

william A. Galston, University of Texas at Austin

Reaching the Peasant Farmer: Organization Theory and Practice in Kenya. By David K. Leonard. (Chicago: The University of Chicago Press, 1977. Pp. xxi, 297. \$19.00.)

This study of the effectiveness of the agricultural extenson service in Kenya is written for the use of the extension practitioner and for students of organization behavior. Both audiences are well served, although this review discusses only those aspects of most interest to scholars.

Leonard has devised several "partial" measures of extension agent productivity (agricultural informedness, for example) which he be- 
lieves provide a better indication of the dependent variable, junior extension agent output, than the more commonly used "comprehensive" measures. He considers four sets of independent variables -extension agent motivation, the authority system of the extension organization, agents' peer group organization, and "the structures used by the [extension] organization to achieve different types of work behavior." (p. 24)

The author presents a thorough and well-written discussion of his findings, including a list of 19 principles for the reformation of agricultural administration. He argues that the effect of Kenyan extension policy is to accentuate the gap between rich and poor farmer. The Ministry concentrates effort on the progressive (rich) farmer to produce greater economic returns and a more rapid spread of innovations. Leonard sees this as politically unsound, and he takes issue with the logic of the innovation diffusion model. He argues that in this model the less progressive farmer will suffer because he is in the second group to accept the innovation. The real economic benefits go to the farmer who can sell first to the market. The author proposes that extension agents should increase the number of farmers served to include the moderately progressive, thus giving many more farmers the chance to take part while the profits are still high. But as the author notes, free market forces are the cause of the profit limitaton. By diffusing innovations more rapidly, the negative effects of free market forces will appear more quickly. Leonard's model may mean economic disaster for more farmers than the government model. According to Leonard's reasoning, if we wish to close the gap between rich and poor farmer, it seems that extension efforts should be concentrated on the middle or poor farmer. Put the less progessive farmer first on the market with new products. Leonard assumes, of course, that such farmers will actually accept innovations presented directly by the extension agent.

Leonard's book is of value to a wide range of students of African politics, as well as to the extension practitioner and student of organization behavior. He tests many aspects of Euro/American organization theory in this African setting and concludes that the theory is valid cross-culturally. His analysis of the relative importance of ethnic and authority cleavages in conflict situations in Kenyan organizations provides important insight into one of Africa's most common political problems-ethnic conflict within the nation-state. 
He concludes that "the actions of the superordinate group in the organization determine which of the two [cleavages] will predominate." (p. 236). Equally of interest is the author's discussion of African attitudes on the development process. (pp. 250-257) Overall, however, Leonard's major contribution, like those of only a few other authors, is his stress on the rural areas as the critical factor in understanding African politics. A host of rural factors have been ignored or downplayed by students of African politics. The continuing and increasing economic exploitation of rural people by urban- and middle class-centered politicians is now a crucial aspect of most African societies. This is the locus of the major political conflict today for most African states. Leonard centers our attention on his locus.

MARK w. DELANCEY, University of South Carolina

Quest for Equilibrium: America and the Balance of Power on Land and Sea. By George Liska. (Baltimore: The Johns Hopkins University Press, 1977. Pp. xxii, 254. \$14.95.)

Professor Liska's new book, written primarily for specialists, is at once provocative, unorthodox, and engaging. Using a methodology he terms "analogico-historical," Liska brings to bear equilibrium theory (especially emphasizing balance-of-power, alliance, and parity-evolving considerations) in a tightly reasoned broad stroke examination of first the European state system prior to World War I, then the contemporary scene.

In Part One Liska argues that the pre-World War I European balance-of-power system collapsed because of its inability to deal satisfactorily with a recurrent interstate problem (the land vs. sea power schism); specifically, the system failed to provide for the evolution of a satisfactory parity (overall equivalence) mix between a structurally ascending continental state (Germany) and a declining insular power (Britain). The catalyst for the downfall was the active involvement of a second ascending land power (Russia) whose presence intensified structural dilemmas and perceptual divergences, as well as radically shortening the time available for 